Utah State University

DigitalCommons@USU

1974

\title{
The Role of Pin Cherry (Prunus Pensylvanica L.) in the Maintenance of Stability in Northern Hardwood Ecosystems
}

P. L. Marks

Follow this and additional works at: https://digitalcommons.usu.edu/aspen_bib

Part of the Forest Sciences Commons

\section{Recommended Citation}

Marks P.L. 1974. The role of pin cherry (prunus pensylvancia I.) in the maintenance of stability in northern hardwood ecosystems. Ecological Monographs. 44(1):73-88.

This Article is brought to you for free and open access by the Aspen Research at DigitalCommons@USU. It has been accepted for inclusion in Aspen Bibliography by an authorized administrator of DigitalCommons@USU. For more information, please contact

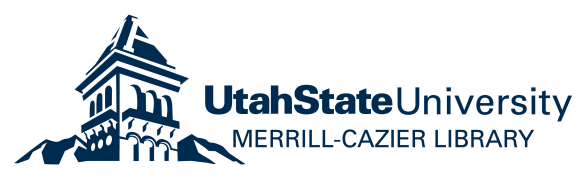


Reprinted from Ecological Monographs

Vol. 44, No. 1, Winter 1974

pp. $73-88$

Made in the United States of America
A Report of Reserich of the Comel

Agricultural Experiment Stati

\title{
THE ROLE OF PIN CHERRY (PRUNUS PENSYLVANICA L.) IN THE MAINTENANCE OF STABILITY IN NORTHERN HARDWOOD ECOSYSTEMS ${ }^{1}$
}

\author{
P. L. MARKS \\ Section of Ecology and Systematics, Cornell University, Ithaca, New York 14850
}

\begin{abstract}
The design of the life cycle of pin cherry (Prunus pensylvanica L.), a successional species common on disturbed sites throughout much of the northern hardwood and boreal forest ecosystems, assures that its occurrence is integrated into the pattern of disturbance in the climax ecosystem. The combination of buried seed strategy and the mobility offered through avian consumption of fruits ensures reasonably large populations of buried, viable seeds in the soils of forests well after the disappearance of pin cherry from a particular site. Soil sampling data indicate that sufficient numbers of viable pin cherry seeds reside in the soils of second-growth forests in central New Hampshire to account for the dense stands frequently observed after cutting or burning. Further, germination of these buried seeds is apparently triggered by some factor(s) associated with formation of a large gap. By age 25 or 30 , when pin cherry individuals are dying rapidly, sufficient numbers of seeds have been produced and disseminated in a dormant condition for the cycle to renew itself with the subsequent occurrence of major disturbance.

In high density stands pin cherry grows rapidly, with early attainment of canopy closure (high leaf area index), and rapid attainment of high values of net annual production and nutrient accumulation.
\end{abstract}

Key words: Biomass; nutrient cycling; primary productivity; revegetation; succession.

\section{INTRODUCTION}

The question of how temperate forests reproduce and maintain themselves cannot be separated from the question of how they respond to different kinds of disturbances. It is helpful to consider a complex disturbance gradient, embracing both severity and frequency of disturbance. At one extreme, when disturbances are frequent and severe, communities may actually depend upon the occurrence of a particular kind of disturbance such as fire for their maintenance and persistence (Sernander 1936, Mutch 1970). The process of community repair under such conditions typically involves a phasic replacement cycle of species (Hanson and Churchill 1961), at least some of which are successional (Jones 1945, Watt 1947, Anderson 1967, Barclay-Estrup and Gimingham 1969, Barclay-Estrup 1970, Loucks 1970) except under climatic extremes where the distinction between successional and climax species breaks down (Muller 1940, 1952, Shreve 1942). At the other end of the gradient, when disturbances tend to be rare and minor, forest reproduction involves the replacement of individuals (or small groups) by other individuals which, though often of a different species, are not typically successional. Most forest regeneration under natural conditions seems to fall somewhere between these extremes.

Both extremes of the gradient involve intracommunity changes (Hanson and Churchill 1961), which

\footnotetext{
${ }^{1}$ Received July 6, 1972; accepted May 14, 1973.
}

implies not only that they are normal processes that have been operating through evolutionary time in the maintenance of forest communities, but also that any successional species participating in the repair process are integral components of the larger community even though they may be absent from the terminal (cli$\max$ ) forest. The present paper provides data supporting the interpretation of successional species as important functional components of the larger ecosystem. I first consider what is known about general responses of forest ecosystems to disturbance and then concentrate on one such category of responses, primarily in terms of its effect on restoration of tight (closed), steady-state, nutrient cycling thought to be characteristic of mature, undisturbed ecosystems. Disturbance is defined here as physical leveling of vegetation, or parts of vegetation, whether natural or man-induced.

\section{General responses to disturbance}

The precise way in which a forest ecosystem responds to a disturbance depends on many factors too complex and poorly understood in their interrelationships to be discussed individually. General patterns of response, however, are apparent and can be discussed in two broad groups: (1) response through reorganization of vegetation established prior to disturbance; and (2) response through vegetation that becomes established following disturbance.

Examples of structural reorganization of vegetation following disturbance would include (1) the lateral 
encroachment into an opening by the crowns and roots of trees surrounding the opening; (2) the production of epicormic branches by undamaged trees surrounding or within an opening; (3) the production of stump sprouts and root suckers by damaged individuals within an opening; and (4) the release of advance reproduction (i.e., seedlings and saplings) established within an opening.

Following disturbance, there will always be a gap or opening formed, whether the result of the gradual death of a single tree or the destruction of an area of forest. In other terms, a gap, whatever its size, represents a temporary reduction in the utilization of available nutrients, light, and moisture, and consequently a local and temporary enrichment of these factors. Smaller gaps will tend to be closed by the inward extension of crowns and epicormic branches, and larger gaps will tend to be filled by stump sprouting and the release of reproduction in combination with other species that may become established following disturbance. In the absence of specific data, the relative importance of each type of regeneration is difficult to evaluate, although, with the possible exception of epicormic branching, each has been shown to be quite important under different conditions.

Thus, the small gaps formed by the gradual elimination of isolated, blight-stricken, American chestnut (Castanea dentata ${ }^{2}$ ) trees in the Great Smoky Mountains were often filled entirely by the lateral growth of surrounding trees before seedlings and saplings could reach the canopy (Woods and Shanks 1959). In the Southern Appalachians (and other areas) hardwood sprout growth following cutting is often vigorous (M. V. Hoover, personal communication), and probably represents the most important component of recovery in these forests. Sernander (1936) has described Norway spruce (Picea abies) forests in Sweden in which the most important means of regeneration was advance reproduction. On a regular basis the spruce was able to germinate, become established, and undergo suppression at a height of $1 \mathrm{~m}$ or so beneath the undisturbed canopy. Growing on unstable soils, the overstory individuals were particularly susceptible to windthrow, causing the formation of extensive gaps that eventually were filled by the previously suppressed saplings.

The second broad pattern-response through individuals that become established following disturbance-includes both direct seeding into a gap and germination of dormant seeds in place at the time of disturbance.

Seed weight and periodicity of good seed years are two critical factors affecting the probability that seed of a given species will reach a given gap in time to

\footnotetext{
${ }^{2}$ Plant nomenclature is after Fernald (1950) unless authority is given.
}

participate in the regeneration of that gap. The mobility conferred upon a species by lightweight seeds becomes more advantageous as gap size increases (Salisbury 1942), for colonization of the central portions of large gaps may be restricted to species whose propagules can be carried considerable distances by wind (and other vectors). Watt (1925) has described the tendency for seedlings of the lighter-seeded Fraxinus excelsior $\mathrm{L}$. to be found commonly in the central portions of gaps, and for those of the heavier-seeded Fagus sylvatica $\mathrm{L}$. to be restricted generally to the periphery. The seed of species incapable of more or less constant annual production of seed would be less likely to reach a gap than that of a species capable of such production. Quite obviously light-seededness and relatively constant annual production of seed combine to offer a species a high potential for reaching, and thus for colonizing, a newly formed gap.

Response of vegetation to disturbance through buried seeds and its significance are discussed in the following sections both in general terms and in the specific context of the present study.

\section{Life History of PIN Cherry}

\section{Pin cherry succession}

Through much of the northern hardwood and boreal forest ecosystems, pin cherry (Prunus pensylvanica) is a common successional species restricted to sites that supported forest vegetation prior to disturbance; it is not common in abandoned pastures or old fields. A fast-growing, short-lived species, pin cherry is further restricted to colonization of sites larger than about 0.1 ha $(0.25$ acres). During the first 2-3 yr following disturbance, Rubus idaeus and to a lesser extent $R$. hispidus and $R$. allegheniensis are important codominant species, yielding to pin cherry and other species upon closure of canopy.

One major determinant of the succession is the density of pin cherry stems, which in turn depends on the population of buried, viable seeds. When pin cherry is very dense, closure of canopy occurs rapidly as adjacent crowns become contiguous, and Rubus declines in abundance after 3 yr or so. Succession subsequently proceeds in two relatively discrete phases. The first is characterized by pin cherry as the only overstory species and a sparse understory. The second phase, which begins after about 25-35 yr in New Hampshire, involves dominance of the tolerant (of shade) species, sugar maple and beech (balsam fir is important further north), both of which are able to survive beneath the closed pin cherry canopy (Fig. 1).

At intermediate densities, pin cherry may be codominant with other fast-growing species like yellow birch (Betula alleghaniensis), paper birch (B. papyrifera), and quaking aspen (Populus tremuloides), fol- 


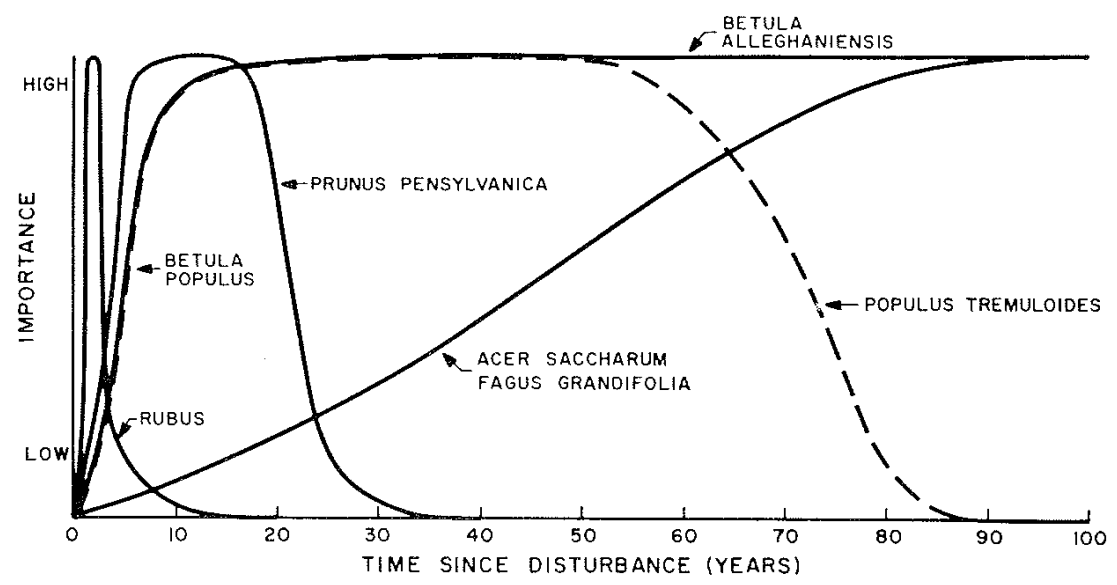

FIg. 1. Diagrammatic representation of the importance of different species along a time sequence following disturbance of a typical northern hardwood forest.

lowing the brief flourish of Rubus. In contrast to high-density pin cherry successions, the transition to the terminal vegetation at intermediate densities is quite gradual because of the diversity of life spans; beginning with pin cherry, species are sequentially eliminated at different times and may gradually be replaced in turn by members of the terminal vegetation. Indeed, yellow birch may become established soon after disturbance and persist as an important component of the northern hardwood ecosystem (Fig. 1).

The successional pattern is quite variable in lowdensity pin cherry stands where dominance is shared. by many species including Rubus, striped maple (Acer pensylvanicum), paper and yellow birch, quaking aspen, and stump sprouts of cut trees. Rubus may persist for $5 \mathrm{yr}$ or more, providing the stand remains relatively open. Throughout much of north-central New Hampshire this pattern is common on large disturbed sites, particularly clear-cuts, where one often finds local patches of aspen, other areas dominated by pin cherry, and still others by hardwood sprout growth, especially beech (Fagus grandifolia) and, on poorly drained sites at lower elevations, red maple (Acer rubrum). In such stands, the rate of canopy closure is slower than in stands of high or intermediate pin cherry density. At the same time, it is not known whether the relatively open nature of the stand may make more rapid the transition to the terminal vegetation, because species like sugar maple and beech, which are present but suppressed beneath dense pin cherry canopies, gain dominance at an earlier stage.

\section{Fugitive strategy}

Successional plant species, typically unable to maintain themselves continuously on a given site, are not usually conspicuous components of the climax ecosystem. Inevitably, however, a disturbance will create conditions that favor their germination, establishment, and growth. Perhaps the most important factor limiting the ability of such species to colonize a disturbed site is the availability of seed, which must come either from a successional stand in close proximity (direct seeding) or from storage in the soil following prior colonization of the same site (or a combination of the two). Accordingly, successional species have evolved at least two different dissemination strategies. One relies exclusively on the continuous input of seed from outside the site; the other relies largely on storage in the soil of dormant seed.

Species with the first strategy have been termed fugitive species by Hutchinson (1951), who notes the important role that good dispersal mechanisms play in permitting such species to colonize suitable local habitats as they become available. Because their occupancy of a given site is usually successional or temporary, fugitive species tend to persist in a kaleidoscopic and shifting pattern of local populations (Wilson 1965, Bailey and Poulton 1968). Most woody successional species have adopted the fugitive strategy.

The success of a fugitive species depends in large measure on its potential for seed dispersal. Consequently, for most fugitive species evolutionary selection has resulted in a substantial decline in seed weight with a concomitant increase in both seed mobility and the number of seeds produced per unit energy invested in sexual reproduction (Salisbury 1942), and a corresponding decrease in periodicity of seed years. This selection has been made at the expense of stored energy reserves in the seed. In some species, notably certain pines, reduction in seed size has apparently resulted from the tendency of seed predators to feed preferentially on large-seeded species (Smith 1970). For climax forest tree species, 
which typically become established under the closed conditions of the undisturbed forest, selection has tended toward large-seededness (large amount of stored energy and/or large embryo), thereby increasing the probability of successful establishment by permitting substantial root growth prior to, or concurrently with, the emergence of leaves (Watt 1925, Stebbins 1971). As an alternative to light-seededness, some fugitive (and many nonfugitive) species depend on animals for dissernination (Grant 1958).

The successful colonization of a disturbed site by a fugitive species depends on the coincidence of sev. eral largely independent events: (1) a good seed year; (2) migration of the seed from another site; (3) the proper timing of seed arrival with the time of disturbance, so that seed arrives neither so far in advance of the disturbance that its viability is lost before conditions become favorable for germination, nor so long after disturbance that other species have become established in large numbers (Weigle and Frothingham 1911); and (4) microclimate favorable for germination and estabiishment. Offsetting this dependence, most fugitive species are light-seeded, generally exhibit less periodicity in annual seed production than do heavy-seeded species, and thus can achieve wide dissemination of large numbers of seeds on a more or less annual basis.

\section{pin cherry as a buried seed species}

The buried seed strategy depends on a prolonged dormancy $^{3}$ mechanism (Quick 1961) and accumulation of seeds in the soil, and has the important advantage of seed being in situ prior to colonization. Most species that have adopted the buried seed strategy are herbaceous (Livingston and Allessio 1968); indeed pin cherry is the only arborescent species in the Northeast demonstrated to exhibit this strategy. I chose to work on pin cherry both because it is often an important component of regeneration following disturbance in northern hardwood and boreal forest ecosystems and because observations of its occurrence in relation to available seed sources suggested the possibility of a buried seed strategy.

Numerous reports suggest that pin cherry arises from buried seed (Douglas 1889, Chittenden 1905, Flaccus 1959, Ahlgren 1966, H. I. Baldwin, personal communication, H. J. Lutz, personal communication, D. A. Marquis, personal communication, R. S. Pierce, personal communication), but only one study (Olmsted and Curtis 1947) reports data on actual seed counts in the soil. To determine the extent to which

\footnotetext{
"I use the term "dormancy" in the sense of Wareing (1966) or of Harper's (1957) "innate dormancy" which results in a lack of germination due to certain properties of the seed itself (immature embryo, impermeable seed coat, etc.).
}

pin cherry seeds are resident in the soils of relatively undisturbed forests in north-central New Hampshire, $\mathrm{I}$ took one hundred and nine $0.09-\mathrm{m}^{2}\left(1-\mathrm{ft}^{2}\right)$ soil samples along two transects, $2,500 \mathrm{~m}$ and $800 \mathrm{~m}$ in length, at the Hubbard Brook Experimental Forest in West Thornton, New Hampshire, and along one 2,200-m transect at the Bartlett Experimental Forest in Bartlett, New Hampshire. Both areas support relatively well-developed, second-growth northern hardwoods with boreal forest species gaining importance at higher altitudes (about $520 \mathrm{~m}$; Hutnik, 1955 and Bormann et al. 1970 give detailed descriptions of these forests). In neither forest was pin cherry present except for scattered, dying individuals, although the relatively decay-resistant bark plus dead, standing individuals indicated that the species had been more prevalent in the recent past (Bormann et al. 1970).

Each transect, the direction of which was an arbitrary compass bearing in an uphill direction, was divided into segments $100 \mathrm{~m}$ long. Two samples, 3.66 $\mathrm{m}(12 \mathrm{ft})$ apart and on a line perpendicular to and bisected by the transect, were taken at a random distance along each $100-\mathrm{m}$ segment. When a potential sample was obstructed by a tree or large rock, I took another sample $1.8 \mathrm{~m}(6 \mathrm{ft})$ further from the transect, and repeated this until $x$ located an unobstructed sample. No sample was taken within about $8 \mathrm{~m}(25 \mathrm{ft})$ of a standing pin cherry tree, whether living or dead. With the aid of a machete, I removed each soil sample by carving around a wooden frame to a depth of $10-12 \mathrm{~cm}(4 \mathrm{in})$-into or below the $A_{2}$ horizon-unless I encountered a large rock or rotting $\log$, in which case I took the sample only to the depth of the obstacle.

Each sample was washed through two differentsized soil sieves, the larger of which excluded litter and other coarse debris, and the smaller retained lesser debris and all pin cherry seeds and parts thereof.

Potential viability was determined by flotation. In general, aborted seeds ${ }^{4}$ were hollow and floated but since some of these sank, all sinkers were cracked and those with a white embryo were called viable. Actual viability could not be determined because young (or recently collected) seeds will not readily germinate for reasons discussed later. I grouped the remaining seeds as follows: whole empty seeds (endocarp intact but embryo aborted); perfect endocarp halves (endocarp cracked smoothly along suture); tooth-marked seeds (tooth marks of small

"The fruit of Prunus is a drupe. Not long after dissemination, the exocarp and mesocarp (the fleshy parts of the fruit, together referred to as the pericarp) are decomposed or consumed, leaving the hard endocarp (stone or pit) with the embryo and seed coat inside. "Seeds" here refers to the embryo, seed coat, plus endocarp. 
TaBle 1. Summary of pin cherry seed content in soils of Hubbard Brook and Bartlett Forests. Data are expressed as numbers of seeds per $0.09 \mathrm{~m}^{2}\left(1 \mathrm{ft}^{2}\right)$

\begin{tabular}{|c|c|c|c|c|c|}
\hline & Viable: & $\begin{array}{l}\text { Whole } \\
\text { empty } \\
\text { endocarps }\end{array}$ & $\begin{array}{l}\text { Perfect } \\
\text { endocarp } \\
\text { halves }\end{array}$ & $\begin{array}{c}\text { Seeds } \\
\text { consumed } \\
\text { by mammals }\end{array}$ & Others \\
\hline \multicolumn{6}{|c|}{ Hubbard Brook } \\
\hline \multicolumn{6}{|l|}{ Transect I } \\
\hline Mean & 4.4 & 4.9 & 4.0 & 12.4 & 11.1 \\
\hline SE & 0.8 & 1.3 & 1.4 & 5.2 & 6.0 \\
\hline $\begin{array}{l}\text { No. of } \\
\text { samples }\end{array}$ & 50 & 32 & 23 & 34 & 23 \\
\hline \multicolumn{6}{|l|}{ Transect II } \\
\hline Mean & 5.1 & 5.6 & 4.1 & 11.9 & 9.1 \\
\hline $\mathrm{SE}$ & 2.5 & 5.1 & 2.8 & 9.2 & 6.8 \\
\hline $\begin{array}{l}\text { No. of } \\
\text { samples }\end{array}$ & 15 & 15 & 15 & 15 & 15 \\
\hline \multicolumn{6}{|l|}{ Bartlett } \\
\hline Mean & 2.6 & 3.4 & 1.3 & 5.4 & 3.9 \\
\hline SE & 0.6 & 1.0 & 0.3 & 1.4 & 1.4 \\
\hline $\begin{array}{l}\text { No. of } \\
\text { samples }\end{array}$ & 44 & 44 & 44 & 44 & 44 \\
\hline \multicolumn{6}{|l|}{ Total } \\
\hline Mean & 3.8 & 4.4 & 2.6 & 9.0 & 6.9 \\
\hline SE & 0.6 & 1.1 & 0.7 & 2.5 & 2.2 \\
\hline $\begin{array}{l}\text { No. of } \\
\text { samples }\end{array}$ & 109 & 91 & 82 & 93 & 82 \\
\hline
\end{tabular}

mammals visible on cracked endocarp); and fragments (pieces of endocarp that did not fit into any of the above categories).

Despite the large variation from sample to sample, even between samples $3.66 \mathrm{~m}(12 \mathrm{ft})$ apart, the average number of viable pin cherry seeds, $494,000 /$ ha $(200,000 /$ acre $)$ and $345,800 /$ ha $(140,000 /$ acre; Table 1) at Hubbard Brook and Bartlett respectively, is sufficiently large to account for the dense young stands frequently observed after burning or cutting in New Hampshire.

Olmsted and Curtis (1947) report approximately 247,000 and 494,000 pin cherry (species of Prunus verified by Olmsted, personal communication) seeds per hectar $(100,000$ and $200,000 /$ acre $)$ in two beech-birch-maple forests in Maine. Although these values are similar to those reported here, their data are based on only four $0.09-\mathrm{m}^{2}\left(1-\mathrm{ft}^{2}\right)$ samples per stand, and insufficient information is given as to whether the sample was limited to viable seeds.

\section{Dissemination}

The distribution of pin cherry seeds in the forest floor is influenced by (1) prior colonization of the site by pin cherry; (2) dissemination of fruits by birds that excrete or regurgitate the endocarp and seed at a distance from their source; and (3) small mammals that tend to shift the distribution of seeds toward more or less discrete aggregations or caches (Ahlgren 1966). Casual observations have revealed caches of pin cherry seeds at Hubbard Brook and
Bartlett, and three striking examples were found in the sample data $(64,101$, and 164 seeds consumed by mammals in three $0.09-\mathrm{m}^{2}$ soil samples). It seems likely, however, that small mammals are not an important influence on the distribution of pin cherry seeds except on a small, local scale.

Although difficult to quantify, the ability of birds to disseminate pin cherry seeds seems to be great. McAtee (1910) lists 39 species of birds that feed on Prunus, Martin et al. (1951) report 47 species of upland gamebirds and songbirds that feed on 3 species of Prunus, and Olmsted and Curtis (1947) report 33 birds and 15 mammals that consume Prunus.

Older reports suggest that birds may carry the fruits of pin cherry (and other species of Prunus) for considerable distances (Hill 1883, Bolles 1890, Chapman 1903, McAtee 1926), especially late-nesting species like waxwings (Bombycilla cedrorum $)^{5}$ and to a lesser extent robins (Turdus migratorius) (S. Rothstein, personal communication), grosbeaks (Pheucticus ludovicianus), thrushes (Hylocichla ustulata and $H$. mustelina), and other species, once territorial behavior breaks down (F. Sturgess, personal communication). Pin cherry fruits generally ripen during the first 2 wk in August in north-central New Hampshire. Saunders (1911) described the routine tendency of nesting cedar waxwings to fly about a quarter of a mile to feed in black cherry (Prunus serotina) trees. In a single robin's nest 145 cherry stones (no species given) were counted by Adams (1923), who noted that this did not include some stones left in the field when the nest was collected. Proctor (1897:412) observed disgorgement of cherry stones (no species given) by wood thrush nestlings as well as "a fair handful of the stones in each nest." Similarly, Baily (1897) reported the disgorgement of cherry stones (no species given) by young robins and usually found 10-15 stones in the nests of the robin, wood robin, and catbird. I have observed the feeding of a fledgling waxwing by a mature waxwing that would ingest typically five pin cherry fruits, fly 100 $m$ or so to the waiting fledgling, regurgitate the fruits intact one by one, and place them in the fledgling's beak, after which they would both fly off, presumably excreting the seeds at a considerable distance from their origin. By imprisoning a brood of young cedar waxwings in a wire cage, Bolles (1890:290) observed the feeding behavior of the parent birds: "During the twelve days of their captivity the young were supplied with 8,400 cherries [pin cherry], or one cherry a bird every six minutes. . . . On the average the old bird or birds made 140 visits a day, bringing five cherries, each time. One was carried in the beak, and the others were jerked up from the

"Terminology follows American Ornithologists' Union (1957). 
throat one by one until all of the five young were fed." Birds, especially the late-nesting waxwings and, when territoriality breaks down, thrushes, robins, grosbeaks, and others could be quite important in disseminating pin cherry fruits.

\section{Fruit production}

The potential for fruit production in pin cherry is high despite its short life span of about $30 \mathrm{yr}$ in New Hampshire. Dominant individuals mature sexually during their fourth growing season, although fruits are not produced in large quantities until several years hence. For a single open-grown tree judged to be $15 \mathrm{yr}$ old and producing a good crop of fruits, I measured fruit production per unit area of ground surface by counting every fruit on the tree, including fallen fruits, and measuring the area of canopy projection $\left(1,300\right.$ fruits over an area of $4.5 \mathrm{~m}^{2}$ or $\left.50 \mathrm{ft}^{2}\right)$. This figure includes a small allowance for bird consumption: the difference between the number of green, fruitless pedicels and the number of fallen fruits was taken as an estimate of avian consumption; brown and withered pedicels were assumed to support aborted fruits and were excluded. On the average, 26 fruits were produced per $0.09 \mathrm{~m}^{2}$ or approximately $2,761,500$ fruits $/$ ha $\cdot$ yr $(1,118,000$ fruits/acre $\cdot y r)$, assuming a pure stand of pin cherry. Leak, Yelenosky, and Marquis (unpublished report) found $2,323,500$ pin cherry seeds/ha yr $(940,688$ seeds/ acre $\cdot$ yr) in a 25 -yr-old stand in the Bartlett Forest previously described. Because pin cherry contributed only $33 \%$ of the total basal area in the partictlar stand investigated and because fruit production was nearly equivalent to that of the pure stand (extrapolated from a single individual), many more seeds may be produced by older pin cherry trees ( 25 vs. $15 \mathrm{yr}$ ), or, more likely, either the 15-yr, open-grown tree was not at its mast peak or the greater foliage overlap in a closed stand may lead to greater fruit production per unit area (or both).

The further observation that the masting cycle is short (every 2-3 yr) reinforces the notion that in its relatively short production period-15 yr conservatively (from age 10 to 25 ) - a pin cherry stand is able to produce a large number of seeds. To estimate this number I assume that (1) the figures for the open-grown tree can be extrapolated to a closed stand; (2) the figures for the open-grown tree represent the peak of the mast cycle; (3) fruits are produced in large numbers every 3rd yr (equal to the figure for the open-grown tree, 26 fruits $/ 0.09 \mathrm{~m}^{2}$ ); and (4) in the intervening years $25 \%$ of this figure is produced. I suspect that these assumptions lead to an underestimation of fruit production as (1) the periodicity in mast cycles is probably somewhat less than 3 yr on the average; (2) the open-grown tree sampled may not have been at its mast peak, as already suggested; (3) occasionally more than $25 \%$ of the mast peak may be produced in one or both of the intervening years; and (4) some fruits are produced by trees younger than 10 and older than $25 \mathrm{yr}$. From age 10 to 25, then, based on the above assumptions, about 16 million fruits/ha $(6.4$ million/acre $)$ would be produced. During mast years, fruit is probably produced well in excess of what birds and other animals can consume, leaving many to fall to the ground to accumulate in time. Such excess production of fruit has been observed for Rubus (Adams 1923), which is consumed by an even larger number of birds and mammals than is Prunus (Martin et al. 1951).

\section{Germination}

The soil sampling data (Table 1) indicate that the seed of pin cherry is resident and alive in the soils of relatively undisturbed forests in New Hampshire (second-growth forests, 50-60 yr old). Two different rhythms of germination could be postulated: (1) germination could occur mostly on an annual basis, as is the case for Prunus serotina (Hough 1960), with seedlings surviving only in large openings, where conditions of light and moisture are favorable for establishment and where allelopathic chemicals produced by overstory trees are absent; or (2) germination could occur irregularly in response to a major disturbance.

The presence of occasional pin cherry seedlings beneath the canopy of undisturbed forests suggests that at least some germination occurs on a regular or annual basis. Such germination could explain the presence in the soil of perfect halves of endocarp (Table 1); these halves are produced every time a seed germinates. The major disadvantage of this rhythm of germination is that there would have to be a significant and continuous input of seed to support a reservoir of viable seeds in the soil in excess of annual losses to unsuccessful germinants (those that germinate in the absence of a major disturbance). This drawback would become serious once pin cherry died out of a stand, because seed would then have to be carried in from another stand.

To test the likelihood of each mode of germination, I carefully removed intact eight soil samples from the undisturbed forest, approximately $30 \times 40 \times 12 \mathrm{~cm}$, using a machete, and placed them in wooden flats, which were then taken to an old field about $5 \mathrm{~km}$ ( 3 mi) from the forest. The flats were placed on a wooden platform above the ground, fully exposed to sunlight. They were watered twice during the experiment. The samples were taken on June 25, 1967, from beneath old or dead pin cherry trees to ensure sufficient seed content, and by July 31 I counted a total of 65 pin cherry seedlings. 
A limitation to this experimental approach is that neither the total number of viable seeds in the sample nor their age can be determined. Nevertheless, the large number of seedlings strongly suggests that most seeds do not germinate on a regular basis beneath the undisturbed canopy. It is highly unlikely that the rate of annual germination is even close to 67 seeds $/ \mathrm{m}^{2}$, the figure obtained by translating the results from the flat experiment to a land area basis. Such a germination rate would imply a complete annual turnover of the resident viable seed population, even when allowance is made for the fact that these samples contained more than the average number of viable seeds $\left(40 / \mathrm{m}^{2}\right.$; Table 1$)$.

Furthermore, in $3 \mathrm{yr}$ of observations in many mature stands I have seen only scattered and occa. sional pin cherry seedlings in small openings (caused by the death of one or two trees) or beneath the uninterrupted canopy of the climax forest. Yet large numbers of seedlings, arising from buried, dormant seeds, are found soon after cutting or burning. The seeds deposited irt situ during the development of a pin cherry stand, then, probably remain dormant in the soil and germinate in response to a major disturbance. Some seeds, especially those with thin or more permeable endocarps, may germinate prematurely (prior to disturbance), producing occasional seedlings as well as perfect endocarp halves.

Laboratory experiments were designed to test the effect of the following treatments on germination: (1) removal of pericarp; (2) removal of endocarp; (3) different regimes of alternating temperatures; and (4) different moisture regimes (seeds were allowed to dry 1-15 days before water was added). Approximately 12,000 ripe fruits were picked from trees in the vicinity of Hubbard Brook. The pericarp (thin outer skin plus fleshy pulp) was manually removed from 3,000 fruits to simulate the physical, though not the chemical, effects of ingestion or regurgitation. Each group of fruits was placed in varnished, hardware-cloth containers (varnish prevented metallic contamination) lined with fiberglass screening; these were then placed beneath the litter layer of the undisturbed forest at Hubbard Brook until early spring the following year, when they were transported to the laboratory. The seeds were placed in cheesecloth and buried in moist vermiculite for cold room storage at $4^{\circ} \mathrm{C}$.

None of the differences in moisture (drying period) or temperature had an effect on germination. Mechanical removal of endocarps caused a large increase in germination (from $0 \%$ to a mean of $45 \%$ ), indicating that the endocarp is impermeable to some substance such as water or oxygen (or both), or that the endocarp might be producing an inhibitor (or both of the above). Removal of pericarp had no effect on germination, although before possible chemical effects from ingestion or regurgitation (digestive enzymes, acids, etc.) can be eliminated, seeds would have to be passed through birds. Nichols (1934) passed 200 pin cherry seeds through a captive cedar waxwing and could get only four of these to germinate subsequently. Of 200 other seeds from which the endocarp was removed at one end, Nichols reported 34\% germination, results confirmed by those reported here. Somewhat different results were obtained by Hilton et al. (1965). They found low pin cherry germination (generally less than $10 \%$ ), but only slight differences in germination between seeds with intact endocarps and seeds whose endocarps were removed or in other ways treated (soaking in $\mathrm{NaOH}$ or $\mathrm{H}_{2} \mathrm{SO}_{4}$ ).

Any explanation of the germination behavior of pin cherry must account for two facts: (1) that the presence of the endocarp limits germination significantly in recently collected seed; and (2) that under natural conditions germination occurs predominantly in response to major disturbance. Accordingly, germination appears to be a two-phase process. The first involves the aging of the endocarp, whether to break down an inhibitor or to make it increasingly permeable to water and oxygen by physical and biological weathering. Krefting and Roe (1949) note that black cherry seeds that were passed through a robin were $9 \%$ lighter than controls, indicating that the digestive process may accelerate the eroding of the endocarp. Thus, some bird-consumed pin cherry seed may, in the absence of a suitable disturbance, either rot (leaving whole empty endocarps) or germinate prematurely (producing perfect endocarp halves).

The second phase of germination, in which the timing is actually controlled, appears to involve a sensing of environment so that germination occurs in response to the altered microclimate, or soil and water chemistry of a disturbed site, or other factors, including release from allelopathic suppression of germination in the undisturbed forest. Because of the overriding influence of the endocarp in recently collected seed, it has not been possible to segregate the effects of these factors individually. Long-term germination studies designed to separate these factors are currently in progress.

\section{Seed longevity}

The question of how long seed viability of pin cherry can be maintained is of crucial importance, because a prolonged dormancy mechanism is im. plicit in the buried seed strategy. At the Bartlett Forest pin cherry frequently is found following the cutting of forests between 40 and $60 \mathrm{yr}$ of age, but is often absent when stands $80-100$ yr old are cut (S. 


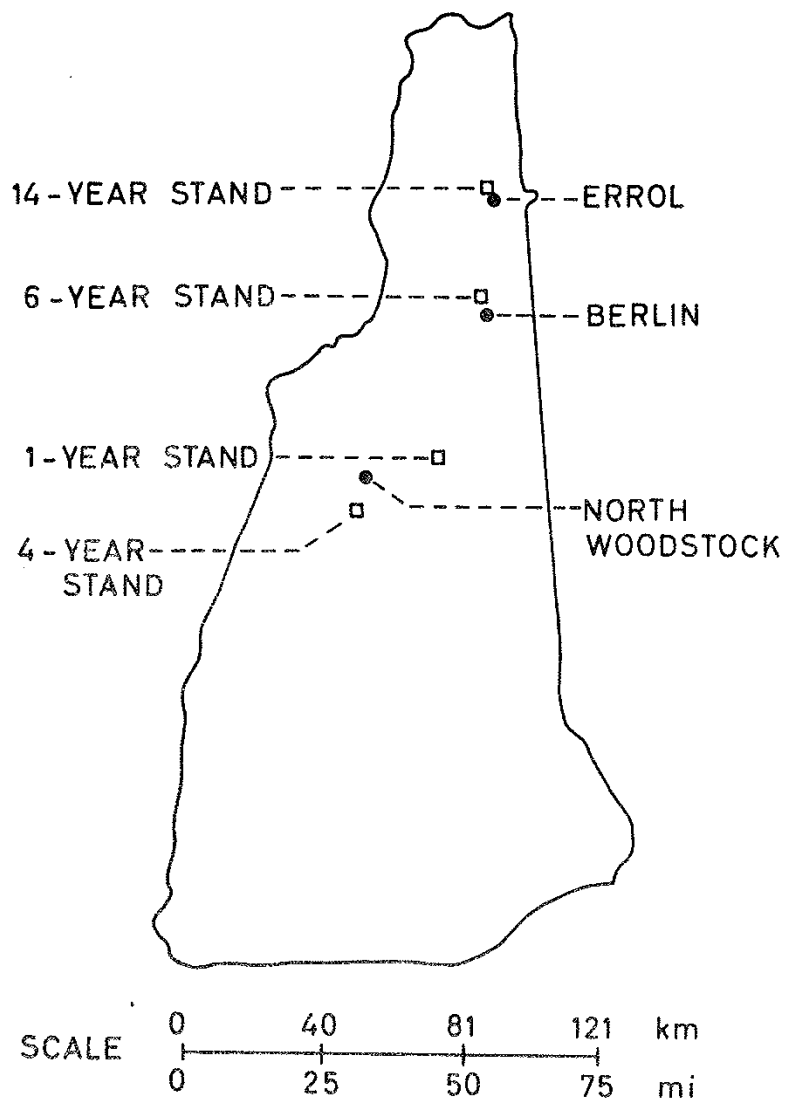

Fig. 2. Locations of 1-, 4., 6-, and 14-yr-old stands in New Hampshire.

Filip, personal communication). The viability of the seeds may be exceeded in the course of development from a second-growth $(40-60)$ to an old-growth $(80-$ $100 \mathrm{yr}$ ) forest. Assuming, conservatively, that most of the pin cherry seed is produced in stands $10-25 \mathrm{yr}$ of age, and that the input of seed from other stands by birds is negligible (a fair assumption only in the case of relatively isolated pin cherry stands), the probable upper limit of longevity is about $50 \mathrm{yr}$ (seed produced during the 10th yr remaining viable through the 16 th $\mathrm{yr}$ ). This estimate will be verified by longterm, buried seed experiments, two of which, by Wendel (1972) and my me, have been recently established.

\section{BIOMASS AND Nutrient ACCUMUlation}

The second major part of this study assesses the impact of revegetation by dense stands of pin cherry on ecosystem function, especially nutrient cycling. The impetus was provided by the large nutrient flush following experimental deforestation and suppression of regeneration with herbicides at Hubbard Brook (Likens et al. 1970). Several questions arose from the outset of this treatment: What are the effects of the natural tendency toward revegetation and recovery of biomass and structure on nutrient export from the ecosystem? Are nutrient losses as large as those reported at Hubbard Brook commonly associated with major disturbance, or are there ways in which under natural conditions nutrient removal in drainage waters is reduced, if not minimized?

There are two complementary research approaches to these questions. The one reported here is to quantify the rates of accumulation of structure and nutrients in the regenerating biomass. The other approach is to monitor stream water chemistry both in the deforested watershed at Hubbard Brook following release from herbicidal applications and in other watersheds at Hubbard Brook cut in different ways but allowed to regenerate immediately after cutting. The latter will be reported in detail by other workers at Hubbard Brook.

\section{Methods}

Revegetation of disturbed sites by pin cherry was measured as accumulated biomass, the rate of accumulation of biomass (as approximated by net annual primary production at different points in time), and accumulation of nitrogen, calcium, sodium, potas sium, and magnesium in the various tissues of the developing biomass. The time dimension was necessarily introduced as I sampled stands in different stages of maturation; it is not practical to follow changes in stand dynamics in a single stand for more than a few years, especially when a destructive sampling scheme is employed. Sampling stands in different stages of maturation risks confounding differences that are truly developmental with differences atributable to site; however, results are likely to be of more general applicability than if a single stand were studied.

To minimize site differences, I devored considerable effort to selecting stands. Broad criteria for selection included the following: all stands were located in north"central New Hampshire; all were on the same geologic formation; all were subjected to the same disturbance, clear-cutting; all had broadly equivalent drainage and elevation; and, most important, all were densely stocked in and dominated by pin cherry. To this end, I visited different-aged stands throughout north-central New Hampshire and selected four as the most representative of the high-density pin cherry succession just described.

The 1-yr-old stand, located in Bartlett, New Hampshire (Fig. 2), occupied a north facing slope about $340 \mathrm{~m}(1,200 \mathrm{ft})$ in elevation. The nature of the vegetation prior to cutting has already been described (Life History Section; also Hutnik 1955).

The 4-yr-old site, previously mentioned in connection with buried seed (Life History Section), was in the Hubbard Brook Experimental Forest (Fig. 2). The site faced south at an elevation of $540 \mathrm{~m}(1,800$ 
TABle 2. Summary of stand characteristics

\begin{tabular}{ccccccccccc}
\hline \hline $\begin{array}{c}\text { Stand age } \\
\text { years }\end{array}$ & $\begin{array}{c}\text { Average } \\
\text { number } \\
\text { of } \\
\text { stems } \\
\text { number } / \mathrm{m}^{2}\end{array}$ & $\begin{array}{c}\text { Height } \\
\text { tallest } \\
\text { tree } \\
\mathrm{m}\end{array}$ & $\begin{array}{c}\text { Average } \\
\text { tree } \\
\text { height } \\
\mathrm{m}\end{array}$ & $\begin{array}{c}\text { Biomass } \\
\text { major } \\
\text { species }_{\mathrm{a} / \mathrm{m}^{2}}\end{array}$ & $\begin{array}{c}\text { Biomass } \\
\text { other } \\
\text { species } \\
\mathrm{g} / \mathrm{m}^{2}\end{array}$ & $\begin{array}{c}\text { Total } \\
\text { biomass } \\
\mathrm{g} / \mathrm{m}^{2}\end{array}$ & $\begin{array}{c}\text { Production } \\
\text { major } \\
\mathrm{species}^{\mathrm{n}} \\
\mathrm{g} / \mathrm{m}^{2}\end{array}$ & $\begin{array}{c}\text { Leaf } \\
\text { indea } \\
\mathrm{m}^{2} / \mathrm{m}^{2}\end{array}$ & $\begin{array}{c}\text { Plot } \\
\mathrm{m} \times \mathrm{m}\end{array}$ & $\begin{array}{c}\text { Number } \\
\text { of } \\
\mathrm{plots}\end{array}$ \\
\hline 1 & 26.0 & 0.85 & 0.40 & 102 & 60 & 162 & 102 & 1.1 & $1 \times 1$ & 10 \\
4 & 16.0 & 5.34 & 3.06 & 2310 & 88 & 2398 & 1309 & 5.5 & $1 \times 1$ & 15 \\
6 & 3.6 & 7.79 & 5.68 & 3603 & 302 & 3905 & 1658 & 6.1 & $1 \times 2$ & 20 \\
14 & 1.2 & 11.26 & 8.70 & 6704 & 108 & 6812 & 1264 & 5.4 & $2 \times 3$ & 20 \\
\hline
\end{tabular}

"Prunus pensylvanica in 1-, 4-, and 14-yr stands.

Prunus pensylvanica and Populus tremuloides in 6-yr stand

ft). Before cutting, the forest was relatively welldeveloped, second-growth, sugar maple-beech-yellow birch ecosystem (Likens et al. 1967 describes the general site and its geology, hydrology, and climate, and Bormann et al. 1970 has a detailed description of the forest).

The 6-yr-old, east-facing site, located in the Androscoggin District of the White Mountain National Forest $13 \mathrm{~km}$ ( $8 \mathrm{mi}$ ) due west of Berlin, New Hampshire (Fig. 2), had an elevation $570 \mathrm{~m}(1,900 \mathrm{ft})$. Quaking aspen was an important codominant species here.

The 14-yr-old stand, at an elevation of $540 \mathrm{~m}$ $(1,800 \mathrm{ft})$ on a gentle, southeast-facing slope, was located about $5 \mathrm{~km}$ ( $3 \mathrm{mi}$ ) west of Errol, New Hampshire (Fig. 2). Except for the greater prevalence of red spruce (Picea rubens) and balsam fir (Abies balsamea), the terminal vegetation of this region is similar to that of Bartlett and Hubbard Brook.

All sample stands are underlain by unstratified glacial till derived from acidic and relatively infertile parent materials. All four sites have predominantly shallow, well-drained soils (spodosols) that are strongly acidic and very stony or extremely stony sandy loams to loams (Lull 1968). Specific soi! classification data are not available except for Hubbard Brook, where extremely stony sandy loams of the Hermon series are found on $25 \%-35 \%$ slopes ( $S$ Pilgrim, personal communication).

The approach to the estimation of biomass and net annual production used here follows Whittaker (1961. 1962, 1965, 1966) and has been called "dimension analysis of woody plants" (Whittaker and Woodwell 1968). Details are given elsewhere (Marks 1971).

For each of the older three stands, samples for chemical analysis (total $\mathrm{N}, \mathrm{Ca}, \mathrm{K}, \mathrm{Mg}$, and $\mathrm{Na}$ ) were taken late in the summer for each tissue: leaves, current twigs, older branch wood plus bark, dead branch wood plus bark, stem wood, stem bark, or stem wood plus bark together when bark could not be removed without contamination or inconvenience, and roots. The procedure used in collecting and processing tissue samples for chemical analysis is described by
Likens and Bormann (1970). Nutrient and biomass data were combined to yield estimates of the amount of each element in each tissue in each stand on a land area basis. Stand characteristics of interest are summarized in Table 2.

\section{Rate of revegetation following disturbance}

Any quantitative approach to revegetation must consider the concept of full occupancy, the somewhat ill-defined vegetative condition when the totality of resources of a site is being exploited fully. Defined primarily in terms of density and size of individuals (Baskerville 1962), full occupancy could be achieved either by a small number of large individuals or a large number of small individuals. Presumably full occupancy would indicate both full exploitation of below-ground rooting space and display of a more or less continuous canopy as determined largely by the competing demands for maximal interception of solar energy and a favorable balance of net photosynthesis for the lowermost branches. When initial stocking or density is high, full occupancy will be attained more rapidly (large number of small individuals) than when initial density is low.

The point at which maximum foliage per unit land surface is attained is thought to be coincident with full occupancy (Baskerville 1962). Further, results reported here indicate that attainment of maximum foliage is more or less coincident with maximum net production, which is expected since the ratio of nonphotosynthetic:photosynthetic shoot surface becomes increasingly unfavorable once maximum foliage mass and leaf area index have been attained, although recent work on bark photosynthesis (Kriedemann and Buttrose 1971, Perry 1971) suggests that many branch surfaces may be photosynthetic.

The high leaf area index (5.5; Fig. 3), the high total net annual production $\left(1,309 \mathrm{~g} / \mathrm{m}^{2}\right)$ (Fig. 4), the presence of nearly equivalent masses of dead and live branches (Table 3 ) indicating attainment of full canopy (death of lowermost branches), and high average density (16 stems $/ \mathrm{m}^{2}$ ) for the 4 -yr stand suggest that full occupancy is attained by the end of 


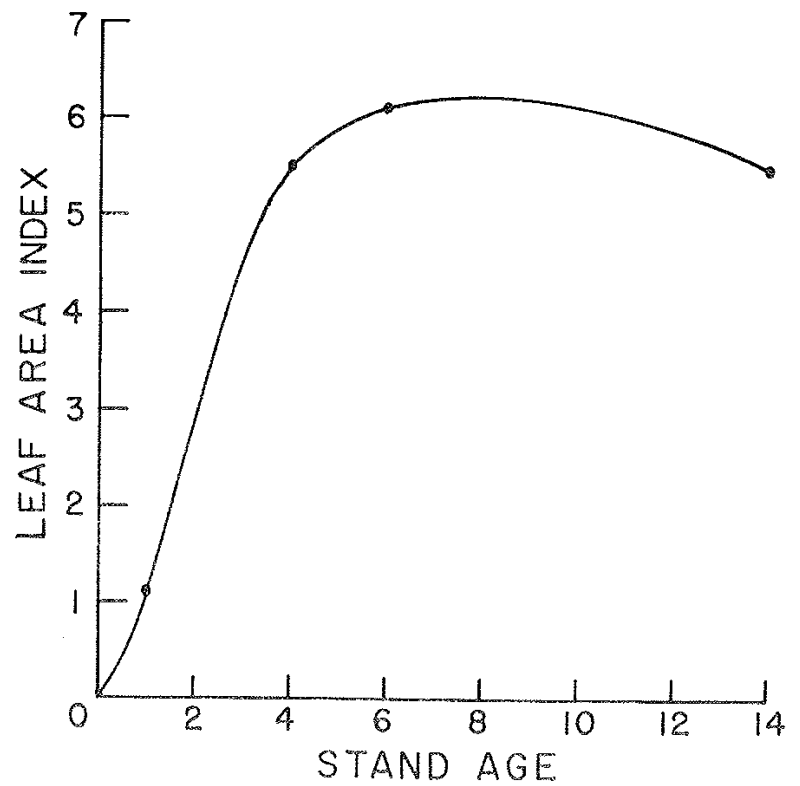

Fig. 3. Relationship of leaf area index to stand age.

the fourth growing season in high-density pin cherry stands. Leaf area indices for the 4- and 6-yr stands fall at the upper end of the range $(4.0-6.0)$ for temperate deciduous forests (Whittaker 1966, Jones 1968, Art and Marks 1971). Attainment of full occupancy suggests not only efficient display of leaf surfaces and high uptake of nutrient elements, but also microclimatic conditions at the soil surface approaching those of the undisturbed forest. These effects are major components of the biotic regulation of the biogeochemical and hydrologic cycles (Marks and Bormann 1972).

Rapid accumulation of biomass relative to stand. ing crop is indicated in the 4-yr stand, where more than half of the estimated $2,318 \mathrm{~g} / \mathrm{m}^{2}$ biomass was produced during the fourth growing season $(1,309$ $\mathrm{g} / \mathrm{m}^{2}$ total net annual production; Table 3, Fig. 4). The rate of accumulation of biomass necessarily decreases with greater stand age as the proportion of perennial woody tissue increases. Values for total

TABlE 3. Summary of biomass by tissue for the different-aged stands

\begin{tabular}{|c|c|c|c|c|c|c|c|c|}
\hline \multirow[b]{2}{*}{ Stand age } & \multicolumn{2}{|c|}{$1 \mathrm{yr}$} & \multicolumn{2}{|c|}{4 yr } & \multicolumn{2}{|l|}{$6 \mathrm{yr}$} & \multicolumn{2}{|l|}{$14 \mathrm{yr}$} \\
\hline & $\mathrm{g} / \mathrm{m}^{2}$ & $\%$ & $\mathrm{~g} / \mathrm{m}^{2}$ & $\%$ & $\mathrm{~g} / \mathrm{m}^{2}$ & $\%$ & $\mathrm{~g} / \mathrm{m}^{2}$ & $\%$ \\
\hline Leaves & 43.9 & 43 & 228.3 & 10 & 273.0 & 7 & 218.5 & 3 \\
\hline Current twigs & - & & 151.4 & 7 & 103.0 & 3 & 29.7 & $<1$ \\
\hline $\begin{array}{l}\text { Stem wood } \\
\text { plus bark }\end{array}$ & 35.7 & 35 & 1377.6 & 59 & 2425.6 & 64 & 4914.8 & 69 \\
\hline Live branches & 0 & & 104.3 & 4 & 328.1 & 9 & 550.3 & 8 \\
\hline Dead branches & 0 & & 107.8 & 5 & 125.6 & 3 . & 422.0 & 6 \\
\hline Roots & 22.4 & 22 & 348.4 & 15 & 518.4 & 14 & 985.6 & 14 \\
\hline Fruits & 0 & & - & & - & & 4.6 & $<1$ \\
\hline Total & 102 & 100 & 2318 & 100 & 3774 & $\overline{100}$ & 7126 & $\overline{100}$ \\
\hline
\end{tabular}

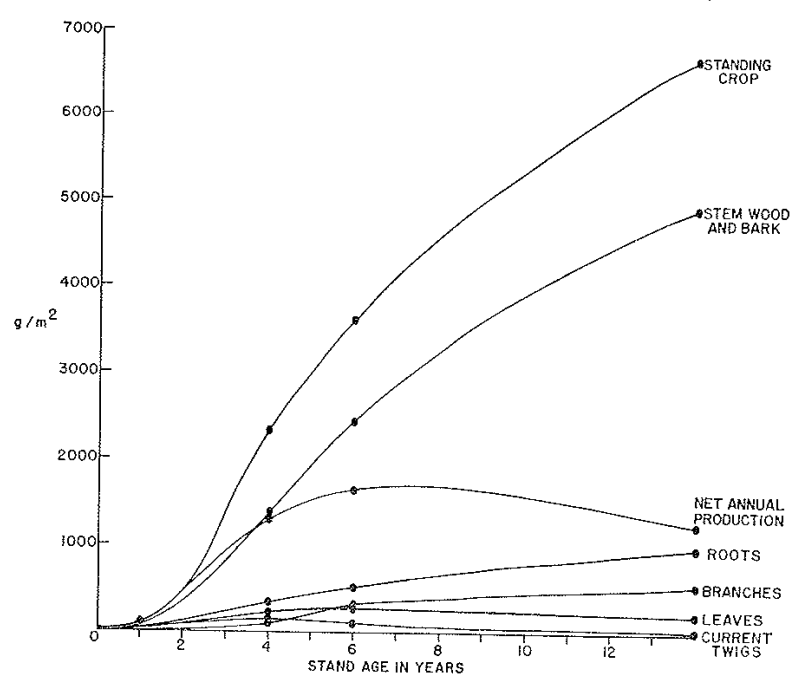

FIG. 4. Trends in biomass accumulation and total net annual production with stand age.

net production for the 4- and 6-yr-old stands compare favorably with other considerably older decidu. ous stands of natural origin (Art and Marks 1971), including the undisturbed forest at Hubbard Brook $\left(1,150 \mathrm{~g} / \mathrm{m}^{2} \cdot \mathrm{yr} ;\right.$ Whittaker et al. 1974); indeed these values fall within (4-yr stand) or exceed (6-yr stand) the estimated range for temperate climax forests (1,200-1,500 g/ $\mathrm{m}^{2}$; Whittaker 1966).

On a land area basis, the amount of foliage increased rapidly to about its maximum value of 220 $\mathrm{g} / \mathrm{m}^{2}$ at $4 \mathrm{yr}$, and largely remained constant through age 14 (Fig. 4). Similar patterns have been reported (Ovington 1957, Baskerville 1962); in other studies (Satoo 1967, Tadaki and Shidei 1960) and Kawahara et al. 1968, both cited in Satoo 1970) more rapid development of foliage is reported, approaching $450 \mathrm{~g} / \mathrm{m}^{2}$ in as few as $3 \mathrm{yr}$, when initial density is high.

Although the absolute amount of foliage remained about the same from $4 \mathrm{yr}$ on, relative investment in leaves decreased with increasing age of stand (Table 3, Fig. 4). For the older three stands, investment in current twigs, both absolute and relative to other tissues, declined with increasing age, while the reverse was generally evident for investment in live branches. Biomass of dead branches and roots, while increasing substantially in absolute mass with increasing age, remained essentially unchanged relative to total biomass. With increasing age, the amount of stem wood and bark increased significantly in both absolute and relative terms.

Broadly, these changes in stand development are similar to those reported for plantations of Pinus sylvestris (Ovington 1957), the major difference being that the time dimension is compressed in the present case, as would be expected for a short-lived, 


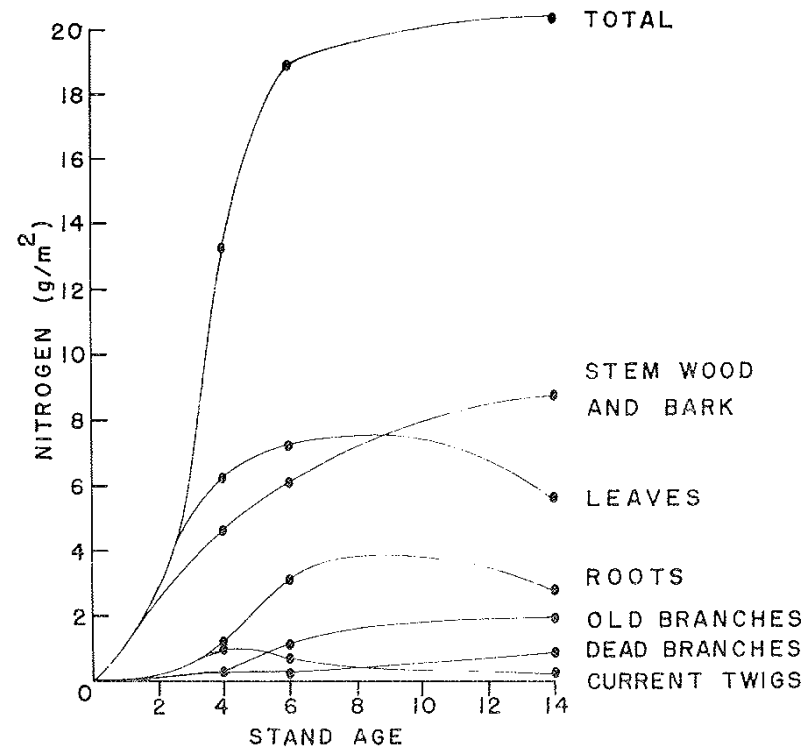

Frg. 5. Trends in nitrogen accumulation and distribution by tissue component with stand age.

successional species. It is likely that these changes are reflected in the development of most stands, provided the initial stocking, whether artificial or natural, is sufficient for attainment of full occupancy. Some stands, especially those of successional species, would tend to exhibit peak net production at an early age, as reported here and elsewhere (peak at 7 yr for plantations of Pinus radiata $\dot{D}$. Don in Australia: Forrest and Ovington 1970); whereas in stands of slower-growing, more tolerant species peak net production would not be realized until considerably later (28 yr for Pinus sylvestris plantations in Britain: Ovington 1957; 40-60 yr for Fagus sylvatica L. plantations in Denmark: Möller et al. 1954).

\section{Nutrient accumulation}

In the younger 4- and 6-yr stands, leaves, which comprise $10 \%$ or less of standing crop on a dry weight basis, are important in the accumulation of nitrogen, potassium, and magnesium, because of relatively high concentrations of these elements. Nearly half the standing crop of nitrogen $\left(6.23\right.$ of $13.63 \mathrm{~g} / \mathrm{m}^{2}$ total) in the 4-yr stand was in leaf tissue (Fig. 5). With increasing age of stand, leaves become less important in this regard as the mass of perennial tissues, particularly stem wood, increasingly dominates the pattern of accumulation despite low concentrations (Fig. 3 and 5, Table 4).

The pattern of accumulation differs somewhat for sodium and calcium. Because of their relatively high calcium content, stem wood and stem bark contained more than half the standing crop of calcium in the 4- and 6-yr stands (Table 4). Leaves, while nearly as important (about $20 \%$ of total calcium), as these two
TABle 4. Standing crop of nutrient elements in the various tissues of the different stands

\begin{tabular}{|c|c|c|c|c|c|}
\hline & $\begin{array}{c}4-\mathrm{yr} \\
\text { Prunus }\end{array}$ & $\begin{array}{l}\text { 6-yr } \\
\text { Populus }\end{array}$ & $\begin{array}{l}\text { 6-yr } \\
\text { Prtinus }\end{array}$ & $\begin{array}{l}6-y r \\
\text { total }\end{array}$ & $\begin{array}{c}\text { 14-yr } \\
\text { Prunus }\end{array}$ \\
\hline \multicolumn{6}{|c|}{$\begin{array}{l}\text { Biomass inventory }-\mathrm{Mg} \\
\qquad\left(\mathrm{g} / \mathrm{m}^{2}\right)\end{array}$} \\
\hline Leaves & 0.59 & 0.24 & 0.35 & 0.59 & 0.65 \\
\hline Current twigs & 0.12 & 0.05 & 0.04 & 0.09 & 0.03 \\
\hline Live branches & 0.04 & 0.06 & 0.08 & 0.14 & 0.24 \\
\hline Dead branches & $0.03^{\mathrm{a}}$ & - & - & $0.03^{a}$ & 0.11 \\
\hline Stem wood & 0.45 & 0.16 & - & - & - \\
\hline Stem bark & 0.34 & 0.17 & $\ldots$ & - & - \\
\hline Stem wood plus bark & - & - & 0.41 & 0.74 & 0.88 \\
\hline Roots & 0.17 & 0.07 & 0.21 & 0.27 & 0.23 \\
\hline Total & 1.75 & & & 1.86 & 2.14 \\
\hline \multicolumn{6}{|c|}{$\begin{array}{c}\text { Biomass inventory-N } \\
\left(\mathrm{g} / \mathrm{m}^{2}\right)\end{array}$} \\
\hline Leaves & 6.23 & 2.69 & 5.04 & 7.73 & 5.75 \\
\hline Current twigs & 0.99 & 0.40 & 0.38 & 0.78 & 0.23 \\
\hline Live branches & 0.31 & 0.31 & 0.84 & 1.15 & 1.93 \\
\hline Dead branches & $0.23:$ & - & - & $0.26^{\circ}$ & 0.89 \\
\hline Stem wood & 2.69 & 0.96 & - & - & - \\
\hline Stem bark & 1.96 & 0.88 & - & - & - \\
\hline Stem wood plus bark & - & - & 4.32 & 6.16 & 8.85 \\
\hline Roots & 1.22 & 0.80 & 2.31 & 3.11 & 2.76 \\
\hline Total & 13,63 & & & 19.19 & 20.41 \\
\hline \multicolumn{6}{|c|}{$\begin{array}{c}\text { Biomass inventory }-\mathrm{Na} \\
\left(\mathrm{g} / \mathrm{m}^{2}\right)\end{array}$} \\
\hline Leaves & 0.0022 & 0.04 & 0.06 & 0.10 & 0.87 \\
\hline Current twigs & 0.0020 & 0.01 & 0.01 & 0.02 & 0.01 \\
\hline Live branches & 0.006 & 0.01 & 0.03 & 0.04 & 0.04 \\
\hline Dead branches & $0.009^{\mathrm{a}}$ & - & - & $0.01^{:}$ & 0.03 \\
\hline Stem wood & 0.0075 & 0.04 & - & -. & - \\
\hline Stem bark & 0.0026 & 0.01 & - & - & - \\
\hline Stem wood plus bark & - & - & 0.16 & 0.21 & 0.16 \\
\hline Roots & 0.1166 & 0.03 & 0.06 & 0.09 & 0.3 \\
\hline Total & 0.132 & & & 0.47 & 1.14 \\
\hline \multicolumn{6}{|c|}{$\begin{array}{l}\text { Biomass inventory--K } \\
\qquad\left(\mathrm{g} / \mathrm{m}^{2}\right)\end{array}$} \\
\hline Leaves & 3.90 & 1.24 & 3.18 & 4.42 & 2.42 \\
\hline Current twigs & 0.95 & 0.20 & 0.19 & 0.39 & 0.12 \\
\hline Live branches & 0.18 & 0.15 & 0.28 & 0.43 & 0.89 \\
\hline Dead branches & $0.05^{\mathrm{a}}$ & - & - & $0.05^{5}$ & 0.19 \\
\hline Stem wood & 2.91 & 0.61 & - & $\cdots$ & - \\
\hline Stem bark & 1.24 & 0.63 & - & - & - \\
\hline Stem wood plus bark & - & - & 1.55 & 2.79 & 4.42 \\
\hline Roots & 1.18 & 0.40 & 1.33 & 1.73 & 1.73 \\
\hline Total & 10.41 & & & 9.82 & 9.77 \\
\hline \multicolumn{6}{|c|}{$\begin{array}{c}\text { Biomass inventory }-\mathrm{Ca} \\
\left(\mathrm{g} / \mathrm{m}^{2}\right)\end{array}$} \\
\hline Leaves & 2.33 & 1.14 & 1.02 & 2.16 & 1.55 \\
\hline Current twigs & 0.74 & 0.20 & 0.24 & 0,44 & 0.21 \\
\hline Live branches & 0.43 & 0.31 & 0.96 & 1.27 & 2.29 \\
\hline Dead branches & $0.28^{\mathrm{a}}$ & - & - & $0.33^{\mathrm{a}}$ & 1.11 \\
\hline Stem wood & 3.47 & 0.54 & - & - & - \\
\hline Stem bark & 2.87 & 0.91 & - & - & - \\
\hline Stem wood plus bark & - & - & 5.30 & 6.75 & 10.32 \\
\hline Roots & 1.60 & 0.63 & 2.10 & 2.73 & 2.00 \\
\hline Total & 11.72 & & & 13.68 & 17.48 \\
\hline
\end{tabular}

" Dead branches sampled only in 14-yr-old stand.

tissues in the 4-yr stand, become less significant with increasing age $(16 \%$ and $9 \%$ of total calcium in the 6- and 14-yr stands respectively, Table 4). For sodium the pattern of accumulation is erratic. Roots contained more than $95 \%$ of the sodium in the 4-yr stand, but only $20 \%$ and $3 \%$ in the 6- and 14-yr stands. Stem wood and bark in the 6-yr stand and 
leaves in the 14-yr stand become more important in sodium accumulation as the importance of roots diminishes (Table 4). The large differences and lack of pattern in the distribution of sodium make difficult interpretation of the accumulation and circulation of this element. Similarly large differences, again without evident trend in relation to stand age, were reported for an age series of Betula verrucosa in Britain (Ovington and Madgwick 1959b).

It is clear from Fig. 3 that there is about as much nitrogen, potassium, and magnesium in the tree biomass at $6 \mathrm{yr}$ as at 14 , whereas calcium and to a lesser extent sodium appear to be accumulating along with biomass at $14 \mathrm{yr}$. The amount of nitrogen accreted at $6 \mathrm{yr}$, about $20 \mathrm{~g} / \mathrm{m}^{2}$, is greater than that in stands of equivalent age and somewhat less than that in stands of considerably greater age. Ovington and Madgwick $(1959 a, b)$ report about $35 \mathrm{~g} / \mathrm{m}^{2}$ of nitrogen in a 33-yr-old plantation of Pinus sylvestris, and for natural stands of Betula verrucosa $1 \mathrm{~g} / \mathrm{m}^{2}$ in a 6-yr stand, $28 \mathrm{~g} / \mathrm{m}^{2}$ in a $24-\mathrm{yr}$ stand, $26 \mathrm{~g} / \mathrm{m}^{2}$ in a $42-\mathrm{yr}$ stand, and $54 \mathrm{~g} / \mathrm{m}^{2}$ in a $55-\mathrm{yr}$ stand. Cole et al. (1967) found $32 \mathrm{~g} / \mathrm{m}^{2}$ of total nitrogen in a 36-yr-old plantation of Pseudotsuga menziesii, and, as would be expected, considerably higher contents of nitrogen have been reported for moist tropical forests (Greenland and Kowal 1960).

\section{Loss vs, accretion}

The conversion of organic matter into water-soluble and thus leachable inorganic forms is clearly promoted by the cutting-herbicide treatment at Hubbard Brook. By suppressing the natural tendency toward revegetation this treatment extended the period of rapid turnover of organic matter, simultaneously increased the volume of water passing through the soil to streams (reduced evapotranspiration), and thus extended the period of rapid removal from the ecosystem of dissolved substances and particulate matter. As a result, the pattern of nutrient circulation characteristic of the undisturbed ecosystem was disrupted severely.

The actual extent to which nutrient losses from the cutover ecosystem at Hubbard Brook would have been reduced, had the regeneration following disturbance consisted of a dense stand of pin cherry, is not easily determined. While it is not possible to say with certainty, the thrust of my discussion of biomass, production, leaf surface relations, and nutrient accumulation strongly suggests that such losses would be minimized. It seems likely that during the first year or two following heavy cutting or other severe disturbance, before attainment of full occupancy, some increase (compared to the undisturbed system) in nutrient losses is inevitable, but in amounts less than those at Hubbard Brook. Curtailment of nutrient losses would be promoted by early attainment of full occupancy, maximum net production, and subsequent rapid accumulation of biomass and nutrients (Marks and Bormann 1972).

Perhaps the most significant evidence in support of this argument is the dramatic decline in streamwater nutrient concentrations on the deforested watershed at Hubbard Brook once revegetation was allowed to proceed (G. E. Likens and F. H. Bormann, personal communication). Revegetation is now proceeding rapidly on that watershed, and pin cherry is a conspicuous component of that vegetation.

\section{General Discussion}

The concept of forest ecosystem stability logically has two components: (1) a certain capacity of the system to resist change or disturbance (resistance to structural change; maintenance of steady-state cycling through biotic regulation of hydrologic and biogeochemical cycles: Bormann et al. 1969, Marks and Bormann 1972); and (2) a certain capacity of the system to recover from disturbance, once the limits of resistance have been exceeded. The relative importance of each component seems to depend primarily on the magnitude (and perhaps the frequency) of the disruptive force. Other factors being equal, the capacity to resist change would become less effective as the disruptive force becomes more severe, and at the same time the capacity to recover from disturbance would become more important. Preston (1969) has mentioned the importance of the latter component, though he emphasizes the probable need for applying different concepts of stability to different biological situations.

In the present context, when the disruptive force is too severe to be resisted, stability may be defined in functional terms as the capacity of the ecosystem to restore rates of nutrient and biomass accumulation to the point where the steady-state nutrient cycling characteristic of the undisturbed system is again realized. Ecosystems that recover more rapidly in terms of restoration of steady-state cycling are thus considered more stable than systems exhibiting slower recovery, a reasonable corollary in view of the large nutrient export measured at Hubbard Brook following experimental deforestation (Bormann et al. 1968, Likens et al. 1969, Bormann and Likens 1970, Likens et al. 1970, Pierce et al. 1970). The role of successional species in the maintenance of stability becomes increasingly important as disturbances become more severe and more frequent.

The definition of stability advanced here integrates instability or disturbance into the process of community maintenance and repair (Whittaker 1953). An important characteristic of any ecosystem, and higher latitude forests (temperate and boreal) in par- 
ticular, is their inability to withstand change once certain environmental limits have been exceeded (Dunbar 1960, 1968, Margalef 1963). This fact is especially important for the stability of a forest that may have required hundreds of years to attain its present level of structural and chemical complexity. Inasmuch as most, if not all, climax forests are eventually subjected to some form of major disturbance (Jones 1945, Curtis 1959, Loucks 1970), including cyclones (Webb 1958), wind storms (Sernander 1936, Stearns 1949), fire (Maissurow 1941), and insect outbreaks, it is reasonable to include the response of the system to these disruptions as a normal part of community maintenance and repair. Indeed, at one extreme some fire-adapted communities are not merely subjected to, but for their persistence actually dependent upon, the occurrence of frequent fires, which may be promoted by flammable properties of the communities themselves (Mutch 1970).

The Hubbard Brook studies indicate the importance of the recovery component of stability when disturbance is severe. It is likely that alterations of hydrologic and biogeochemical cycles similar to those observed after clear-cutting at Hubbard Brook, though probably of lesser magnitude, occur within large gaps regardless of the nature of the disturbance. This in turn suggests that such gaps represent short-term local enrichments in both water and nutrients, which, combined with a lack of competition initially, offer conditions conducive to short-term exploitation. It is hardly surprising, then, that the formation of such a gap is followed by a series of responses, including on the one hand the tendency of established vegetation to close the gap both by growth within the gap and by lateral encroachment from the periphery, and on the other hand by the appearance of new species dependent upon gaps for their persistence (successional species).

The occurrence of such gaps in the past may have led to the evolution of species adapted for exploitation of the temporary enrichment of water and nutrients. However, availability of nutrients and water is a major determinant of growth rate for some woody species (van den Driessche and Wareing 1966, Parsons $1968 a, b)$, so the rapid growth commonly exhibited by successional species like pin cherry may be at least partially a phenotypic expression of greater availability of nutrients and water on disturbed sites.

Following clear-cutting in New Hampshire, a succession of species broadly overlapping in time is commonly observed. Attainment of peak values of net production and maximal fruit production and dissemination for each species is distributed along the time axis. Species of Rubus appear, flourish, complete their life cycles, and decline in importance all within the first few years after disturbance. Pin

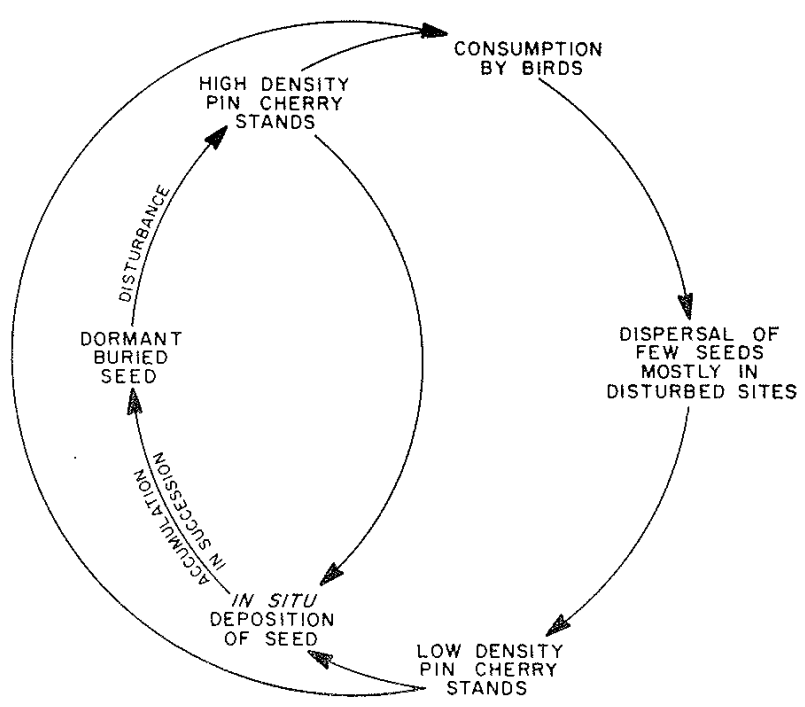

FIG. 6. Representation of high- and low-density pin cherry cycles.

cherry also typically becomes established soon after disturbance but persists for 25 yr or more in New Hampshire (Fig. 1). Significantly, Rubus is thought to exhibit and pin cherry has been shown to exhibit the buried seed strategy. Quaking aspen may become established at the same time as, or a year or so later than, Rubus and pin cherry, and tends to persist for $60 \mathrm{yr}$ or longer. Yellow birch may similarly become established within the first few years following disturbance but persists as a component of the terminal vegetation (Fig. 1). It is remarkable that yellow birch should be able to combine successfully characteristics of both successional and climax species (light-seededness, fast growth rate, relative intolerance of shade, and a long life span).

Pin cherry is particularly well suited for efficient colonization of large gaps. The design of its life cycle assures that its occurrence is integrated into the pattern of disturbance in the climax ecosystem. The combination of the buried seed strategy with the mobility offered through avian consumption of fruits ensures reasonably large populations of buried, dormant, viable seeds in the soils of forests well after the disappearance of pin cherry from a particular site, as attested by the large numbers of viable seeds reported here from soils of relatively mature northern hardwood ecosystems in New Hampshire. The number of seeds in the soils of a large region (northern New England, for example) would in the long run be a function of the frequency of major disturbances, with low-density seed populations and stands occurring when disturbance is rare (outer cycle of Fig. 6), and high density occurring in response to frequent major disturbances (inner cycle of Fig. 6). The effect of frequent (compared to natural disturbances) and repeated cutting for the last $100 \mathrm{yr}$ or so in New 
Hampshire has been to promote the high-density cycle, which is maintained only when on the average major disturbance occurs before the viability of a large fraction of the buried seed population is lost.

Once established, especially if in great numbers, pin cherry grows rapidly, producing large amounts of shoot structure per unit of root mass, with early sexual maturity, low periodicity of fruit production, early canopy closure, and rapid attainment of high leaf area indices and high values of net annual production and nutrient accumulation and turnover. There is a brief but intense burst of production of structure in these high-density situations. By age 25 or 30 , when pin cherry individuals are dying rapidly, sufficient seeds have been produced and disseminated in a dormant condition for the cycle to renew itself with the subsequent occurrence of major disturbance.

The high-density pin cherry cycle promotes ecosystem stability by biotic regulation of ecosystem function (Marks and Bormann 1972). Runoff is reduced as increasing amounts of water are channeled through evapotranspiration. Increasing biotic regulation of function diminishes losses of particulate matter and inorganic dissolved substances and promotes the kind of steady-state buffering exhibited by the undisturbed watersheds at Hubbard Brook. In broad outline the thrust of the present argument has long been recognized: "We may not look upon bird or fire cherry with much favor as a forest tree, but such a tree and raspberry bushes produce a vegetational cover, under whose shade more valuable trees do grow, and further such vegetation will retard erosion of the soil and its runoff much better than a sparse vegetation" (Adams 1923). To deny the role of successional species in the maintenance of forest ecosystem stability is to misunderstand the real significance of stability.

\section{ACKNOWLEDGMENTS}

I thank F. H. Bormann for much invaluable advice, guidance, encouragement, and criticism throughout the course of this study and preparation of the manuscript. Thanks are also due the following who helped and advised me in many different ways: T. Delevoryas, J. S. Eaton, S. Filip, G. M. Furnival, P. A. Harcombe, F. T. Ledig, G. E. Likens, H. J. Lutz, R. S. Pierce, T. G. Siccama, D. M. Smith, G. K. Voigt, and R. H. Whittaker. Financial support was provided by NSF grants GB-6567, GB-6742, GB-14325, and GB-14289 to Bormann and Likens. This is contribution No. 53 of the Hubbard Brook Ecosystem Study. The Hubbard Brook Experimental Forest is maintained and operated by the U.S. Forest Service.

\section{Literature Cited}

Adams, C. C. 1923. Notes on the relation of birds to Adirondack forest vegetation. Roosevelt Wildl. Bull. 1: 487-519.

Ahlgren, C. E. 1966. Small mammals and reforestation following prescribed burning. J. For. 64:614-618.
American Ornithologists' Union. 1957. Check-list of North American birds. Lord Baltimore Press, Baltimore. $691 \mathrm{p}$.

Anderson, D. J. 1967. Studies on structure in plant communities. IV. Cyclical succession in Dryas communities from north-west Iceland. J. Ecol. 55:629-635.

Art, H. W., and P. L. Marks. 1971. A summary table of biomass and net annual primary production in forest ecosystems of the world, p. 1-32. In H. E. Young [ed.] Forest biomass studies. XVth IUFRO Congress. Gainesville, Fla.

Bailey, A. W., and C. E. Poulton. 1968. Plant communities and environmental interrelationships in a portion of the Tillamook burn, northwestern Oregon. Ecology 49:1-13.

Baily, W. L. 1897. Disgorgement of cherry stones again noted. Auk 14:412-413.

Barclay-Estrup, P. 1970. The description and interpretation of cyclical processes in a heath community. II. Changes in biomass and shoot production during the Calluna cycle. J. Ecol. 58:243-249.

Barclay-Estrup, P., and C. H. Gimingham. 1969. The description and interpretation of cyclical processes in a heath community. I. Vegetational change in relation to the Calluna cycle. J. Ecol. 57:737-758.

Baskerville, G. L. 1962. Production in forests. Can. For. Res. Branch, Dep. For. Unnumbered Publ. 83 p.

Bolles, F. 1890 . Young cedar-birds and great crested flycatchers in captivity. Auk 7:290.

Bormann, F. H., and G. E. Likens. 1970. The nutrient cycles of an ecosystem. Sci. Am. 223:92-101.

Bormann, F. H., G. E. Likens, and J. S. Eaton. 1969. Biotic regulation of particulate and solution losses from a forest ecosystem. BioScience 19:600-610.

Bormann, F. H., G. E. Likens, D. W. Fisher, and R. S. Pierce. 1968. Nutrient loss accelerated by clearcutting of a forest ecosystem. Science 159:882-884.

Bormann, F. H., T. G. Siccama, G. E. Likens, and R. H. Whittaker. 1970. The Hubbard Brook ecosystem study: Composition and dynamics of the tree stratum. Ecol. Monogr. 40:373-388.

Chapman, F. M. 1903. The economic value of birds to the state. State of New York For., Fish and Game Comm. 66 p.

Chittenden, A. K. 1905. Forest conditions of northern New Hampshire. USDA, Bur. For., Bull. 55. 100 p.

Cole, D. W., S. P. Gessel, and S. F. Dice. 1967. Distribution and cycling of nitrogen, phosphorus, potassium, and calcium in a second-growth Douglas-fir ecosystem, p. 197-232. In H. E. Young [ed.] Symposium on primary productivity and mineral cycling in natural ecosystems. Univ. Maine Press, Orono.

Curtis, J. T. 1959. The vegetation of Wisconsin: an ordination of plant communities. Univ. Wisconsin Press, Madison. 657 p.

Douglas, R. 1889. The forest: succession of forest growth. Garden For. 2:285-286.

Dunbar, M. J. 1960 . The evolution of stability in marine environments: natural selection at the level of the ecosystem. Am. Nat. 94:129-136.

- 1968. Ecological development in polar regions: A study in evolution. Prentice-Hall, Englewood Cliffs, N.J. 119 p.

Fernald, M. L. 1950. Gray's manual of botany. American Book Co., New York. 1632 p.

Flaccus, E. 1959. Revegetation of landslides in the White Mountains of New Hampshire. Ecology 40: 692-703. 
Forrest, W. G., and J. D. Ovington. 1970. Organic matter changes in an age series of Pinus radiata plantations. J. Appl. Ecol. 7:177-186.

Grant, V. 1958. The regulation of recombination in plants. Cold Spring Harbor Symp. 23:337-363.

Greenland, D. J., and J. M. L. Kowal. 1960. Nutrient content of the moist tropical forest of Ghana. Plant Soil 12:154-174.

Hanson, H. C., and E. D. Churchill. 1961. The plant community. Reinhold, New York. 218 p.

Harper, J. L. 1957. The ecological significance of dormancy and its importance in weed control. 7 th Int. Conf. Plant Protection. p. 415-420.

Hill, E. J. 1883. Means of plant dispersion. Am. Nas. 17:811-820, 1028-1034.

Hilton, R. J., A. S. Jaswal, B. J. E. Teskey, and B. Barabas. 1965. Rest period studies on seeds of Amelanchier, Prunus, and Sorbus. Can. J. Plant Sci. 45:79-85.

Hough, A. G. 1960. Silvical characteristics of black cherry. Northeast. For. Exp. Sta. Pap. 139. 26 p.

Hutchinson, G. E. 1951. Copepodology for the ornithologist. Ecology 32:571-577.

Hutnik, R. J. 1955. Bartlett Experimental Forest. Northeast. Forest Exp. Sta. Pap. 32 p.

Jones, E. W. 1945. Structure and reproduction of the virgin forest of the north temperate zone. New Phytol. $44: 130-148$.

Jones, R. 1968. The leaf area of an Australian heathland with reference to seasonal changes and the contribution of individual species. Aust. J. Bot. 16:579-588.

Krefting, L. W., and E. I. Roe. 1949. The role of some birds and mammals in seed germination. Ecol. Monogr. 19:269-286.

Kriedemann, P. E., and M. S. Buttrose. 1971. Chlorophyll content and photosynthetic activity within woody shoots of Vitis vinifera (L.). Photosynthetica 5:22-27.

Likens, G. E., and F. H. Bormann. 1970. Chemical analysis of plant tissues from the Hubbard Brook ecosystem in central New Hampshire. Yale Univ. Sch. For. Bull. No. 79.25 p.

Likens, G. E., F. H. Bormann, and N. M. Johnson. 1969. Nitrification: Importance to nutrient losses from a cutover forested ecosystem. Science 163:1205-1206.

Likens, G. E., F. H. Bormann, N. M. Johnson, D. W. Fisher, and R. S. Pierce. 1970. Effects of forest cutting and herbicide treatment on nutrient budgets in the Hubbard Brook watershed-ecosystem. Ecol. Monogr. $40: 23-47$.

Likens, G. E., F. H. Bormann, N. M. Johnson, and R. S. Pierce. 1967. The calcium, magnesium, potassium, and sodium budgets for a small forested ecosystem. Ecology 48:772-785.

Livingston, R. B., and M. L. Allessio. 1968. Buried viable seed in successional field and forest stands, Harvard Forest, Mass. Bull. Torrey Bot. Club 95: 58-69.

Loucks, O. L. 1970. Evolution of diversity, efficiency, and community stability. Am. Zool. 10:17-25.

Lull, H. W. 1968. A forest atlas of the Northeast. U.S. For. Serv., Northeastern For. Exp. Sta. 46 p.

Maissurow, D. E. 1941. The role of fire in the perpetuation of virgin forests in northern Wisconsin. $\mathrm{J}$. For. 39:201-207.

Margalef, R. 1963. On certain unifying principles in ecology. Am. Nat. 97:357-374.

Marks, P. L. 1971. The role of Prunus pensylvanica L. in the rapid revegetation of disturbed sites. Ph.D. Dissert. Yale Univ. $119 \mathrm{p}$.
Marks, P. L., and F. H. Bormann. 1972. Revegetation following forest cutting: Mechanisms for return to steady-state nutrient cycling. Science 176:914-915.

Martin, A. C., H. S. Zim, and A. L. Nelson. 1951. American wildlife and plants. McGraw-Hill Book Co., New York. 500 p.

McAtee, W. L. 1910. Plants useful to attract birds and protect fruit. USDA Yearbook for 1909. p. 185-196. 1926. The relation of birds to woodlots in New York State. Roosevelt Wildl. Bull. 4:7-152.

Möller, C. M., D. Müller, and J. Nielsen. 1954. Graphic presentation of dry matter production in European beech. Forstl. Forsøg. Danmark 21:327-335.

Muller, C. H. 1940. Plant succession in the LarreaFlourensia climax. Ecology 21:206-212.

- 1952. Plant succession in arctic heath and tundra in northern Scandinavia. Bull. Torrey Bot. Club 79:296-309.

Mutch, R. W. 1970. Wildland fires and ecosystemsa hypothesis. Ecology 51:1046-1051.

Nichols, G, E. 1934. The influence of exposure to winter temperatures upon seed germination in various native American plants. Ecology 15:364-373.

Olmsted, N. W., and J. D. Curtis. 1947. Seeds of the forest floor. Ecology 28:49-53.

Ovington, J. D. 1957 . Dry matter production by $p_{i n u s}$ sylvestris. Ann. Bot. (N.S.) 21:287-314.

Ovington, J. D., and H. A. I. Madgwick. 1959a. The growth and composition of natural stands of birch. I. Dry-matter production. Plant Soil 10:271-283.

Ovington, J. D., and H. A. I. Madgwick. 1959b. The growth and composition of natural stands of birch. II. The uptake of mineral nutrients. Plant Soil 10:389-400.

Parsons, R. F. 1968a. The significance of growth-rate comparisons for plant ecology. Am. Nat. 102:595-597.

$1968 \mathrm{~b}$. Ecological aspects of the growth and mineral nutrition of three mallee species of Eucalyptus. Oecol. Plant. 3:121-136.

Perry, T. O. 1971. Winter-season photosynthesis and respiration by twigs and seedlings of deciduous and evergreen trees. For. Sci. 17:41-43.

Pierce, R. S., J. W. Hornbeck, G. E. Likens, and F. H. Bormann. 1970. Effect of elimination of vegetation on stream water quantity and quality. Symposium on the results of research on representative and experimental basins. Wellington, N.Z. IASH-UNESCO. p. 311-328.

Preston, F. W. 1969. Diversity and stability in the biological world. Brookhaven Symposia in Biology, Number 22. p. 1-12.

Proctor, T. 1897. Disgorgement among song-birds. Auk 14:412.

Quick, C. R. 1961. How long can a seed remain alive? USDA Agric. Yearbook for 1961. p. 94-99.

Salisbury, E. J. 1942. The reproductive capacity of plants. G. Bell, London.

Satoo, T. 1967. Primary production relations in woodlands of Pinus densiflora, p. 51-80. In H. E. Young [ed.] Symposium on primary productivity and mineral cycling in natural ecosystems. Univ. Maine Press, Orono.

1970. A synthesis of studies by the harvest method: primary production relations in the temperate deciduous forests of Japan, p. 55-72. In D. E. Reichle [ed.] Analysis of temperate forest ecosystems. Springer-Verlag, New York.

Saunders, A. A. 1911. A study of the nesting of the cedar waxwing. Auk 28:323-329. 
Sernander, R. 1936. Granskär och Fiby urskog. En studie över stormluckornas och marbuskarnas betydelse $\mathrm{i}$ den svenska granskogens regeneration. [Engl. summary] Acta Phytogeogr. Suec. 8:1-232.

Shreve, F. 1942. The desert vegetation of North America. Bot. Rev. 8:195-246.

Smith, C. C. 1970. The coevolution of pine squirrels (Tamiasiurus) and conifers. Ecol. Monogr. 40:349371.

Stearns, F. W. 1949. Ninety years change in a northern hardwood forest in Wisconsin. Ecology 30:350-358.

Stebbins, G. L. 1971. Adaptive radiation of reproductive characteristics in angiosperms, II: Seeds and seedlings. Annu. Rev. Ecol. Syst. 2:237-260.

van den Driessche, R., and P. F. Wareing. $1966 . \quad$ Nutrient supply, dry-matter production, and nutrient uptake of forest tree seedlings. Ann. Bot. (N.S.) 30:657-672.

Wareing, P. F. 1966. Ecological aspects of seed dormancy and germination, p. 103-121. In J. G. Hawkes [ed.] Reproductive biology and taxonomy of vascular plants. Pergamon, Oxford.

Watt, A. S. 1925. Development and structure of beech communities. J. Ecol. 13:27-73.

1947. Pattern and process in the plant community. J. Ecol. 35:1-22.

Webb, L. J. 1958. Cyclones as an ecological factor in tropical lowland rain forest, north Queensland. Aust. J. Bot. 6:220-228.

Weigle, W. G., and E. H. Frothingham. 1911. The aspens; their growth and management. USDA For. Serv. Bull. 93. p. 1-35.

Wendel, G. W. 1972. Longevity of black cherry seed in the forest floor. USDA For. Serv. Res. Note NE149. $4 \mathrm{p}$.

Whittaker, R. H. 1953. A consideration of climax theory: The climax as a population and pattern. Ecol. Monogr. 23:41-78.

—— 1961. Estimation of net primary production of forest and shrub communities. Ecology 42:177-180. 1962. Net production relations of shrubs in the Great Smoky Mountains. Ecology 43:357-377. - 1965. Branch dimensions and estimation of branch production. Ecology 46:365-370.

1966. Forest dimensions and production in the Great Smoky Mountains. Ecology 47:103-121.

Whittaker, R. H., G. E. Likens, and F. H. Bormann. 1974. The Hubbard Brook ecosystem study: Forest biomass and production. (In press)

Whittaker, R. H., and G. M. Woodwell. 1968. Dimension and production relations of trees and shrubs in the Brookhaven Forest, New York. J. Ecol. 56:1-25. Wilson, E. O. 1965. The challenge from related species, p. 7-27. In H. G. Baker and G. L. Stebbins [ed.] The genetics of colonizing species. Academic Press, New York.

Woods, F. W., and R. E. Shanks. 1959. Natural replacement of chestnut by other species in the Great Smoky Mountains National Park. Ecology 40:349-361. 